\title{
Distribution of bird communities in University of Lampung, Indonesia
}

\author{
DIAN ISWANDARU ${ }^{1, \boldsymbol{v}}$, N. NOVRIYANTI ${ }^{1,2}$, IRWAN SUKRI BANUWA $^{1}$, SUGENG P. HARIANTO $^{1}$ \\ ${ }^{1}$ Department of Forestry, Faculty of Agriculture, Universitas Lampung. Jl. Prof. Dr. Soemantri Brojonegoro No.1, Bandar Lampung 35141, Lampung, \\ Indonesia. Tel.: +62-721-701609, `email: ndaruforest57@gmail.com \\ ${ }^{2}$ Komunitas Konservasi Indonesia WARSI. Jl. Inu Kertapati No.12, Pematang Sulur, Telanaipura, Kota Jambi 36361, Jambi, Indonesia
}

Manuscript received: 13 March 2020. Revision accepted: 17 May 2020.

\begin{abstract}
Iswandaru D, Novriyanti N, Banuwa IS, Harianto SP. 2020. Distribution of bird communities in University of Lampung, Indonesia. Biodiversitas 21: 2629-2637. University of Lampung (UNILA), Indonesia holds a variety of potential biodiversity, especially birds, species that are sensitive to environmental changes. It is necessary to detect early bird communities spread across UNILA before the physical of this higher institution of education (including vegetation distribution that supplies birdlife) begins to change even further. The method used is the Field Method and Concentration Count Method. Research and Experimental Garden (ST1), Integrated Field Laboratory (ST2), Soccer Field (ST3), Deer Breeding (ST4), Arboretum and Green Lane (ST5) were observed for 2 months. The results showed that 37 bird species from 21 families and 8 orders were spread in each study location. The Passeriformes group dominated in all five study sites with the number of species and the number of families reaching $57 \%$ of all species found. Most bird communities (individuals, species, and families) can be found in the Integrated Field Laboratory (ST2) compared to the other four locations. Diversity index numbers (H '), Evenness (E), and Dominance (D) types at this location also support it even though the overall results of the analysis show that the distribution of bird species is evenly distributed and that no bird species dominate in community building.
\end{abstract}

Keywords: Bird species composition, bird dispersion, birds in Soccer field, campus biodiversity, green campus

\section{INTRODUCTION}

Indonesian is a megadiverse country and has two of the world's biodiversity hotspots (von Rintelen et al. 2017). Based on the global bird diversity data, Indonesia takes the fourth position of the world's richest bird countries lists, after Columbia, Peru, and Brazil, and the first list for endemism (Iskandar et al. 2019) or 17\% of the total birds' species in the world (von Rintelen et al. 2017). It has been recorded 1974 bird species and 527 of them are endemic. Birds are well-known as bioindicators, and they have a significant role in ecosystem functioning and balancing (Tesfahunegny et al. 2016; Kiros et al. 2018). The birds have an important function as agricultural pest controller, weeds controller, plant-pollinator, seed dispersal, and scavengers (Whelan et al. 2008).

Different habitats provide good space for wild birds in an area. One space that provides bird habitat is the University of Lampung (UNILA), one of the green campuses in Bandar Lampung City. UNILA was ranked fourth as a green campus in Sumatra and 18th in Indonesia. UNILA has green areas (arboretum or botanical collection, green lane, agroforestry, plantations, rice fields, grasslands, and reservoir water). In the outer part of this campus are urban area settlement, shopping center, some school building, network asphalt road and railway, bus station, and some institutional governance building. So UNILA is a potential area for wildlife, including birds. Unfortunately, birds are sensitive to environmental change (Callaghan et al. 2018). Bird community recognized as one of the most sensitive and easily disturbed species in the development area (Sulaiman et al. 2013). Wildlife destruction through massive natural habitats destruction occurs due to urbanization activity (Hong and Mohd-Azlan 2018). Both urbanization and industrialization are sources of disruption to the bird community. Urbanization activities cause habitat degradation and fragmentation resulting in a decline in overall biodiversity (Naithani et al. 2018).

Identification of birds community is needed to determine important habitats that can be considered in UNILA development. It caused by changes in tree composition not only affect habitat selection (Gabbe et al. 2002; Domokos and Domokos 2016) but also on the structure of bird communities (Rodewald and Abrams 2002; Domokos and Domokos 2016). But, there has not been much study on bird communities in the Bandar Lampung city, specifically the UNILA campus. Previous studies on the bird of UNILA were surveyed that focused mostly on the relationship of bird species diversity to the composition of trees around the building, and the time of the study was conducted in November 2017 - January 2018 with the survey method (Ramadhani 2018). Nurhasanah (2018) focused on bird diversity in the green lane of the UNILA campus, and the time of the study was conducted in December 2017-January 2018 with survey method and point count method. Therefore, the present study based on the distribution and community of birds of UNILA undertaken to fill this gap.

\section{MATERIALS AND METHODS}

\section{Study area}

University of Lampung (UNILA), Bandar Lampung, Indonesia is located at $5^{\circ} 21^{\prime} 52.6$ "S and 105 14 '30.2" $\mathrm{E}$. 
Land use of UNILA divided into arboretum (botanical collection), green lane, integrated field laboratory, experimental garden, Soccer field, deer breeding, and many other institutions building including faculty building. This study location focuses on the green area campus, i.e.:

First station. Faculty of Agriculture experimental garden (ST1) has areas such as water ponds with grass and shrub edge conditions, cassava plantations, bamboo groves, and several planted tree species such as Acacia auriculiformis, Terminalia catappa, Swietenia macrophylla, Hevea brasiliensis, Acacia mangium.

Second station. Arboretum and Green Lane (ST5); UNILA have four arboretums: a) ICT's Arboretum is planted 18 trees dominated by Shorea javanica, Acacia alba, Bauhinia purpurea, Bacaurea dulcis, Peltophorum pterocarpum; b) Faculty of Agriculture's Arboretum is planted 64 trees dominated by Gmelina arborea, Dalbergia latifolia, Swietenia macrophylla, Acacia mangium, Tectona grandis, Canarium vulgare, Podocarpus imbricatus, Pterosprmum javanicum, Gnetum gnemon; c) Library's Arboretum is planted 8 trees dominated by Enterolobium cyclocarpum, Euginia polyantha; d) Language Laboratory's Arboretum is planted 32 trees dominated by Swietenia macrophylla, Paraserianthes falcataria, Collocedrus decurius, Baccaurea dulcis, Pterospermum javanicum, Micellia champala, and Gmelina arborea. Green lane is planted Mimosops elengi, Lagerstroemia speciosa, Manilkara kauki.

Third station. Integrated Laboratory (ST2) has several areas such as rice fields, reservoir water, plantations, and agroforestry. tree species planted are generally Paraserianthes falcataria, Swietenia macrophylla, Gmalina arborea, Leucaena glauca, Pterospermum javanicum, Acacia auriculiformis, Ficus benjamina, Hevea brasiliensis and bamboo, and several coconut plants. This laboratory is used by students to carry out academic activities such as practice.

Fourth station. Soccer field (ST3) has many planted trees such as Acacia auriculiformis, Tectona grandis, Swietenia macrophylla, Gmelina arborea, Ceiba petandra, Dalbergia latifolia. The tree species grow tightly around the soccer field.

Fifth station. Deer Breeding (ST4) has areas such as reservoir water and area planted tree species such as Samanea saman, Cassia siamea, Tectona grandis, Lagerstroemia speciosa, Delonix regia. The position of reservoir water in the middle of deer breeding area between Tectona grandis that grows tightly in and other trees.

All sites studied located in the middle of campus UNILA together with and roads and institutional buildings, except the integrated laboratories located on the campus edge.
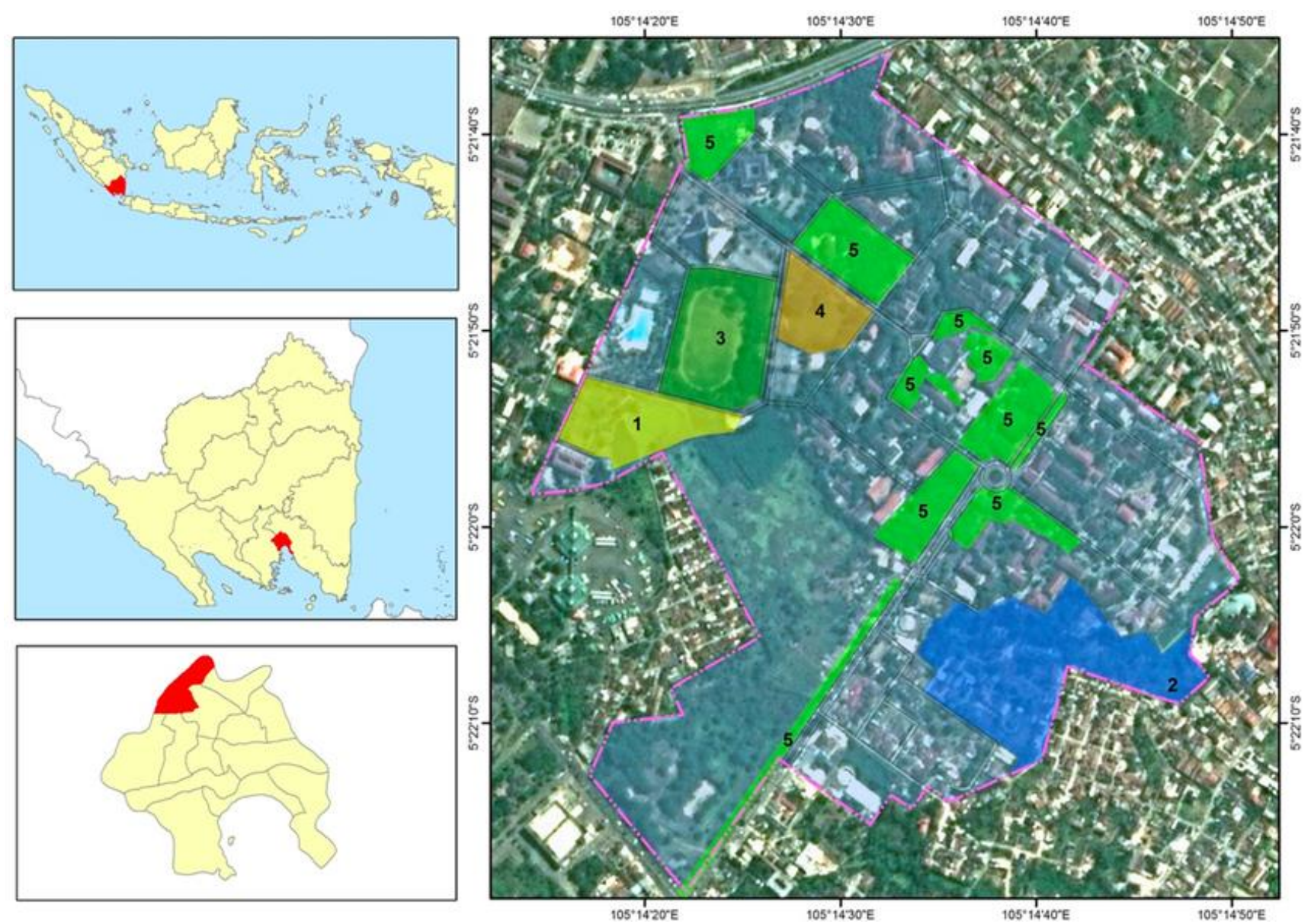

Figure 1. The study area at the campus University of Lampung, Bandar Lampung, Indonesia: 1. ST 1, 2. ST2, 3. ST3, 4. ST4, 5. ST5. 


\section{Bird sampling}

Data collection was carried out during 2018 and stop in 2019, with two seasons counting time, (i) from May to September 2018, and (ii) from October 2018 to April 2019 to record seasonal variation in bird diversity. The field exploration was carried out for three days a week throughout this period to make seasonal diversity and location checklist. Then, birds observation conducted by adapted two different methods to study bird community. The first method was field method and the second method was concentration count method. The field method is carried out while walking following the path in different habitats and stopping at specific points incidentally with inconsistent time (Winara 2016). It was done to observe birds that use vegetation such as tree canopies and others as well as birds that make use of the land surface for its activities. To avoid double-counting, the road that has been passed is no longer traversed. Concentration count method carried out on the spot around the reservoir water with the consideration that it can detect species of water birds that are concentrated around wetlands (Sutopo et al. 2017). Observations were done at a constant time in the morning (06.00 - $09.00 \mathrm{am})$ and evening (3.30 - $6.00 \mathrm{pm})$ during the dry and rainy seasons to increase the probability detecting of the birds' presence. Birds are generally most active in the morning and evening (MacKinnon et al. 2010). Recording and identification are made at every bird encounter directly or through sound. Binocular Nikon Monarach 10x42 and digital camera Nikon D5300 and 70-300 mm telephoto lenses are used as aids. Bird species identification is based on MackKinnon and Phillips (1993) and nomenclature following Gill and Donsker (2018).

\section{Data analysis}

The identified bird grouped by order and family. The number of species and the number of individuals in each habitat was calculated. Furthermore, bird species were grouped according to guild type (feed group) adjusted to the physical condition of the habitat at UNILA consisting of: (i) Insectivorous: Insectivorers on branches or canopy (TFI); Insectivor while flying (FCI); Eating insects by grabbing (SI); Insectivorers on the forest floor (LGI); Insectivor by punching holes in the stem (PT), (ii) Meat eaters: Fish eaters (PS); Predator / Predator (PR), (iii) Seed eaters (GR), (iii) Fruit eaters (FR), (iv) Nectar-eating (NR), (v) Mixed feed eaters (OM).

Data on the types and number of bird species were analyzed using descriptive statistics. Estimation of species diversity at each location is known through diversity index analysis using Shannon-Wiener $\left(\mathrm{H}^{\prime}\right)$ as well as analyzing biodiversity in general (Muhammad et al. 2018). An analysis was also carried out to assess the evenness of species and the dominance of bird species in each study location. We use the Evenness Index of Pielou and Simpson Dominance Index (Fikriyanti et al. 2018). The three index formulations are as follows:

$$
\mathrm{H}^{\prime}=-\sum \frac{n i}{N} \operatorname{Ln} \frac{n i}{N}
$$

$$
\begin{aligned}
& E=\frac{H I}{L n(S)} \\
& C=\sum\left(\frac{n i}{N}\right)^{2}
\end{aligned}
$$

Where:

$\mathrm{H}^{\prime}$ : Diversity Index of Shannon-Wiener

C : Dominance Index of Simpson

E : Evenness Index of Pielou

$\mathrm{Ni}$ : The number of individuals of each species

$\mathrm{N}$ : Total number of individuals of all species

$S$ : the number of species

Ln : Logaritma natural

The criteria used in the Shannon-Wiener diversity index are: (i) if the value $\mathrm{H}<1$ can be defined as a low diversity of bird species; (ii) if the $\mathrm{H}$ value is within 1-3 intervals, it can be defined as a moderate diversity of species; and (iii) if the value of $\mathrm{H}>3$, it can be defined as a high diversity of bird species.

The criteria for the Pielou Evenness Index are if the amount of E closed to 0 , so the level of evenness is low. If the value close to one, so the amount of evenness distribution relatively uniform. The criteria for the Simpson Dominance Index value are that if the $\mathrm{C}$ value is close to 0 , so no particular type dominates a community. If the $\mathrm{C}$ value is close to 1 , so there is a particular type that dominates.

\section{RESULTS AND DISCUSSION}

\section{Bird species in UNILA and their composition in several habitats}

A total number of birds found in UNILA for all-season studied were 37 species. These 37 bird species spread into 21 families and eight orders (Table 1). However, based on season differentiation, the number of species of all habitat types found lower than its total number of birds (Figure 2). Based on Figure 2, the average number of birds in wet season found as 21 species with a maximum as 32 species found. The average number of birds in dry season as 19 species only with maximum species can found as 30 species.

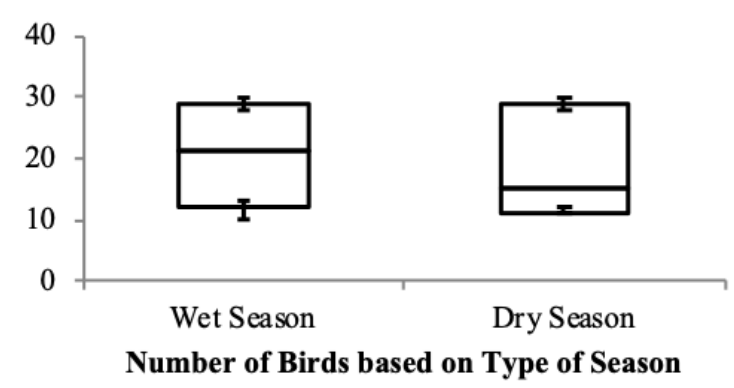

Figure 2. Number of birds species found in all types of habitat in wet and dry season counting. 


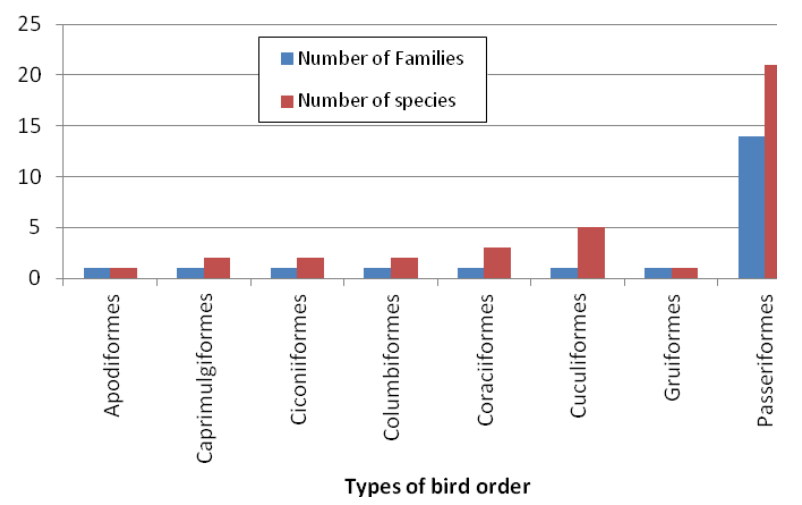

Figure 3. Composition of bird species based on its order at UNILA, Bandar Lampung, Indonesia

This study found the most order of birds is Passeriformes. This order also reaching $57 \%$ of all species found (a high diversity of species), has a species distribution in all habitats UNILA, and belongs to a widespread group (Figure 3). The number of birds that can be found in five study sites also dominated by Passeriformes (Table 2). In much other research, Passeriformes order is the most order that found on all continents (Tietze 2018), including Asia and Africa landscape (Dorrestein 2009; Payevsky 2014). Its findings prove that Passeriformes is the most frequent order of birds in whole area study research.

Analysis at the family level shows that Cuculidae is the family with the highest number of species (14\%) compared to other families (Table 1). However, the Cuculidae family is only found in three locations, namely in the Faculty of Agriculture Experiment Garden (ST1), Integrated Field Laboratory (ST2), and the Arboretum and Green Lane (ST5) (Figure 4). In addition, the Cuculidae is the most common bird family found in the Integrated Field Laboratory (ST2), and the Faculty of Agriculture Experiment Garden (ST1) compared to the Arboretum and Green Line (ST5). Other families from the Integrated Field Laboratory (ST2) and the Experimental Garden Faculty of Agriculture (ST1) evenly the same amount and relatively lack compared by the Cuculidae, Alcedinidae, and Estrildidae families.

Table 1. List of bird species found in several habitats at UNILA, Bandar Lampung, Indonesia for two counting season

\begin{tabular}{|c|c|c|c|c|c|c|c|c|}
\hline Order & Family & Indonesian name & Scientific name & ST1 & ST2 & ST3 & ST4 & ST5 \\
\hline Apodiformes & Apodidae & Walet Linci & Collochalia linchi & + & + & + & + & + \\
\hline \multirow[t]{2}{*}{ Caprimulgiformes } & Caprimulguidae & Cabak Kota & Caprimulgus affinis & + & + & & & + \\
\hline & Caprimulguidae & Cabak Maling & Caprimulgus macrurus & + & + & & & \\
\hline \multirow[t]{2}{*}{ Ciconiiformes } & Ardeidae & Kokokan Laut & Butorides striata & + & & & + & \\
\hline & Ardeidae & Bambangan Merah & Ixobrychus cinnamomeus & + & + & & & \\
\hline \multirow[t]{3}{*}{ Columbiformes } & Coloumbidae & Perkutut Jawa & Geopelia striata & + & + & & & + \\
\hline & Coloumbidae & Tekukur Biasa & Streptopelia chinensis & + & + & + & & + \\
\hline & Alcedinidae & Rajaudang Meninting & Alcedo meninting & + & + & & + & \\
\hline \multirow[t]{2}{*}{ Coraciiformes } & Alcedinidae & Cekakak Sungai & Halcyon chloris & + & + & + & + & + \\
\hline & Alcedinidae & Cekakak Belukar & Halcyon smyrensis & + & + & & & \\
\hline \multirow[t]{5}{*}{ Cuculiformes } & Cuculidae & Wiwik Kelabu & Cacomantis merulinus & + & + & & & \\
\hline & Cuculidae & Wiwik Uncuing & Cacomantis sepulcralis & & + & & & \\
\hline & Cuculidae & Bubut Alang-alang & Centropus bengalensis & + & + & & & \\
\hline & Cuculidae & Tuwur Asia & Eudynamis scolopacea & + & & & & + \\
\hline & Cuculidae & Kedasi Hitam & Surniculus lugubris & + & + & & & + \\
\hline Gruiformes & Rallidae & Koreo Padi & Amaurornis phoenicurus & + & + & & & \\
\hline \multirow[t]{21}{*}{ Passeriformes } & Aegithinidae & Cipoh Kacat & Aegithinia tiphia & + & + & & & \\
\hline & Nectariidae & Madu Kelapa & Anthreptes malacensis & & + & & & + \\
\hline & Artamidae & Kekep Babi & Artamus leucorynchus & + & + & & & \\
\hline & Dicaedae & Cabai-bunga Api & Dicaeum trigonostigma & & + & & + & + \\
\hline & Dicaedae & Cabai Jawa & Dicaeum trochileum & + & + & + & + & + \\
\hline & Hirundinidae & Layang-layang Asia & Hirundo rustica & & + & & & + \\
\hline & Hirundinidae & Layang-layang Batu & Hirundo tahitica & + & + & & & \\
\hline & Campephagidae & Kapasan Kemiri & Lalage nigra & + & + & + & + & + \\
\hline & Laniidae & Bentet Coklat & Lanius schach & + & + & & & \\
\hline & Estrildidae & Bondol Jawa & Lonchura leucogastroides & + & + & & & + \\
\hline & Estrildidae & Bondol Haji & Lonchura maja & + & + & & & \\
\hline & Estrildidae & Bondol Peking & Lonchura punctulata & + & + & + & + & + \\
\hline & Muscicapidae & Sikatan Bubik* & Muscicapa latirostris & & & & & + \\
\hline & Nectariidae & Madu Sriganti & Nectarinia jugularis & + & + & + & + & + \\
\hline & Oriolidae & Kepudang-kuduk Hitam & Oriolus chinensis & & & & & + \\
\hline & Sylviidae & Cinenen Kelabu & Orthotomus ruficeps & + & + & + & + & + \\
\hline & Plocaidae & Gereja Erasia & Passer montanus & + & + & + & + & + \\
\hline & Pycnonotidae & Cucak Kutilang & Pycnonotus aurigaster & + & + & + & + & + \\
\hline & Pycnonotidae & Merbah Cerucuk & Pycnonotus goiavier & + & + & & & \\
\hline & Sittidae & Munguk Beledu & Sitta frontalis & & & & & + \\
\hline & Muscicapidae & Seriwang Asia* & Terpsiphone paradise & & & & & + \\
\hline
\end{tabular}


Table 2. Birds that can be found in five study sites at UNILA, Bandar Lampung, Indonesia

\begin{tabular}{clll}
\hline Ordo & \multicolumn{1}{c}{ Family } & \multicolumn{1}{c}{ Indonesian name } & \multicolumn{1}{c}{ Latin name } \\
\hline Apodiformes & Apodidae & Walet Linci & Collochalia linchi \\
Coraciiformes & Alcedinidae & Cekakak Sungai & Halcyon chloris \\
Passeriformes & Dicaedae & Cabai Jawa & Dicaeum trochileum \\
Passeriformes & Campephagidae & Kapasan Kemiri & Lalage nigra \\
Passeriformes & Estrildidae & Bondol Peking & Lonchura punctulata \\
Passeriformes & Nectariidae & Burungmadu Sriganti & Nectarinia jugularis \\
Passeriformes & Sylviidae & Cinenen Kelabu & Orthotomus ruficeps \\
Passeriformes & Plocaidae & Burung-gereja Erasia & Passer montanus \\
Passeriformes & Pycnonotidae & Cucak Kutilang & Pycnonotus aurigaster \\
\hline
\end{tabular}

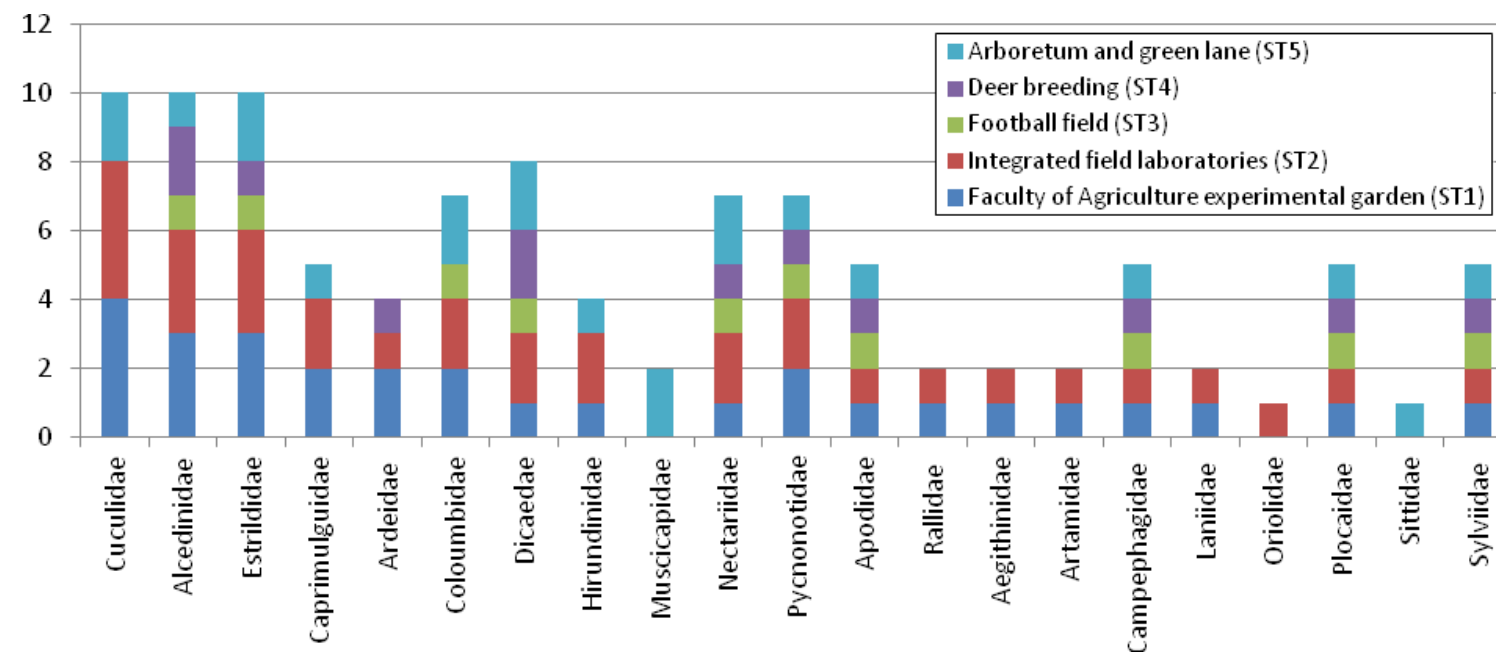

Figure 4. Distribution of bird families in various habitats at UNILA, Bandar Lampung, Indonesia

Based on Figure 4, the Soccer Field (ST3) is also known as location or habitat in UNILA with the least number of birds. The birds found at this location are only in the ten family category. However, the highest number of families in this location was not found, it means the number of species in each family in the ST3 location was the same, namely one species per family (Figure 4). In addition to the Soccer Field habitat, Deer Breeding (ST4) also only found ten families, but at this location, many families were found namely Alcedinidae and Dicaedae. Meanwhile, Arboretum and Green Lane (ST5) are known to have six families with the same type of servings, namely Cuculidae, Estrildidae, Columbidae, Dicaedae, Muscicapidae, and Nectariidae.

This study results also show that some habitats have species that are typical of certain families that adapt to certain habitat conditions. This study found several aquatic birds species of Ardeidae (Butorides striata, Ixobrychus cinnamomeus) and Rallidae (Amaurornis phoenicurus) in the Faculty of Agriculture experimental garden (ST1), Integrated Field Laboratory (ST2), and Deer Breeding (ST4). Furthermore, this research also found birds of the family Aegithinidae (Aegithia tiphia), Centropus bengalensis (family Cuculidae), Amaurornis phoenicurus (Family Rallidae), and Halcyon smyrnensis (family Alcedinidae) that are not found in other habitats, except in ST1 and ST2. Two families, namely Muscicapidae and Sittidae, were only found in the Arboretum and Green Lane (ST5). Birds belonging to the Muscicapidae family are migratory birds, namely Muscicapa latirostris and Terpsiphone paradise. Both migratory birds utilize the ST5 habitat as a stopover site. The Sittidae family is a group of climbing birds that are not found in other habitats, namely Sitta frontalis. These findings indicate that each bird species has a different habitat potential (Figure 5). A habitat favored by certain bird species may not be suitable for other bird species (Paramita et al. 2015). Besides, the presence of waterbirds and migratory birds indicates the importance of the habitat's existence. The wetland's existence is very important for waterbirds because the ecosystem provides suitable habitat for bird populations throughout the year (Ntongani and Andrew 2013), also necessary for migratory birds. After all, it will be part of a network in a migration path that is interconnected (connected) to one another (Xu et al. 2019). 


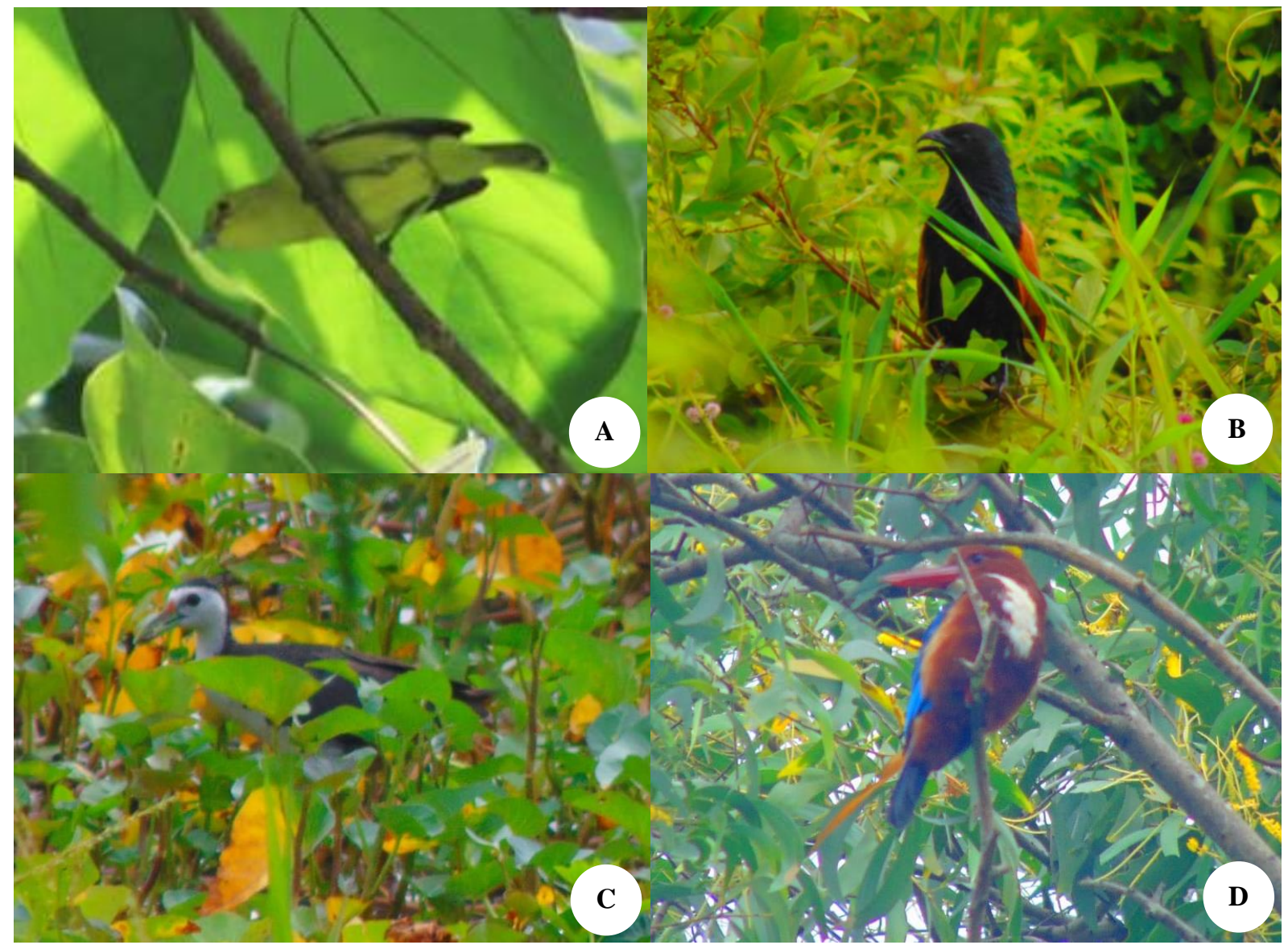

Figure 5. Bird species at UNILA, Bandar Lampung, Indonesia. A. Aegithia tiphia; B. Centropus bengalensis; C. Amaurornis phoenicurus; D. Halcyon smyrnensis

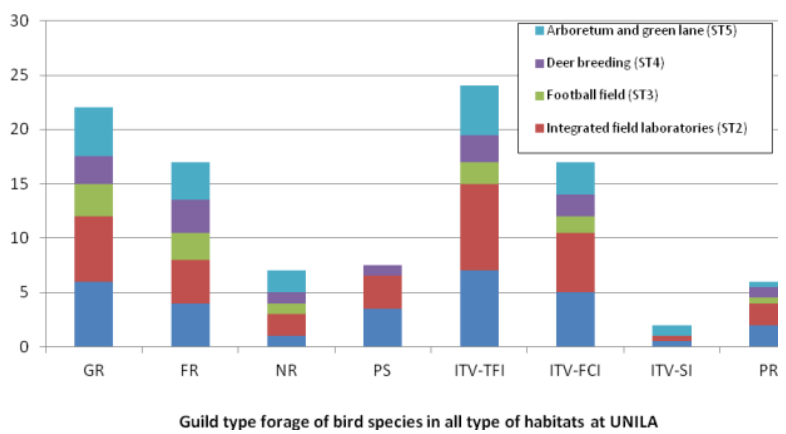

Figure 6. Guild type forage of bird species in habitats at UNILA (granivore (GR); frugivore (FR); nectarivore (NR); carnivore/piscivore (PS); insectivore (ITV-TFI, ITV-FCI, ITV$\mathrm{SI})$; and predators (PR))

\section{Bird guild types in all habitat types}

This study grouped five types of bird feed guilds at UNILA, i.e granivore, frugivore, nectarivore, carnivore/piscivore, insectivore, and predators (Figure 6). The granivore feed guild consists of 6 species (16.22\%), namely Lonchura leucogastroides, Lonchura punctulata, Lonchura maja, Passer montanus, Geopelia striata,
Streptopelia chinensis. The frugivore feed guild consists of 5 species (13.51\%), namely Dicaeum trochileum, Dicaeum trigonostigma, Eudynamis scolopacea, Pycnonotus aurigaster, Pycnonotus goiavier. The nectarivore feed guild consists of 2 species (5.41\%), namely Anthreptes malacensis, Nectarinia jugularis. The carnivore/piscivore feed guild consists of 4 species $(10.81 \%)$, namely Alcedo meninting, Butorides striata, Ixobrychus cinnamomeus, Amaurornis phoenicurus. The insectivore SI feed guild consists of 3 species $(8,11 \%)$ namely Lanius schach, Muscicapa latirostris, Terpsiphone paradise. The insectivore TFI consists of 9 species (24,32\%) i.e Orthotomus ruficeps, Lalage nigra, Cacomantis merulinus, Cacomantis sepulcralis, Surniculus lugubris, Centropus bengalensis, Sitta frontalis, Oriolus chinensis, Aegithinia tiphia. The insectivore FCI consists of 6 species $(16,22 \%)$ i.e Collochalia linchi, Caprimulgus affinis, Caprimulgus macrurus, Hirundo rustica, Hirundo tahitica, Artamus leucorynchus. The Predators feed guild consist of 2 species $(5,41 \%)$ i.e Halcyon chloris, Halcyon smyrensis.

Based on Figure 6, all of the bird feed guilds almost found in every habitat, except carnivore/piscivore and insectivore SI. Among the five types of bird habitat, insectivore TFI is guild type with the highest number of bird species, the lowest are insectivore SI (only one 
species). The insectivore TFI guild type found in all habitat, but mostly found in ST1 habitat as many six species and ST2 habitat as many eight species.

In ST3, this study found that the granivore guild type has the most species (3 species), and each of insectivore FCI and predators only found one species. In ST4, the study found that the frugivore guild type has the most species ( 3 species), and the lowest is insectivore FCI, nectarivore, and predators only found each one species. In habitat type ST5, the guild type with the most species is granivore (5 species), and the lowest is predators (1 species). The carnivore/piscivore guild type is only found in ST1 (4 species), ST2 (3 species), and ST4 (2 species).

Grouping of bird species based on their feeding guild is needed to describe the flow of energy and matter as well as the complexity of the structure of the ecosystem as a bird habitat (Akinpelu 2017; Muhammad et al. 2018). Variations in bird feed guilds found indicate that UNILA is a reasonably suitable habitat for birds. Similar research results for a broader region such as DKI Jakarta found six types of feed guilds, five of which are the same as those found in this study (Rumblat et al. 2016). The bird community located at UNILA is dominated by insectivorous groups, just as it is found elsewhere.

The difference in the number of bird species in feeding guilds found at UNILA in each habitat is influenced by the complexity of habitat structure in supporting more birds to live. The complexity of habitat structures will support a greater number of bird species with a broader foraging strategy (Subasinghe and Sumanapala 2014). Also, guild differences indicate the suitability of the habitat of bird species, as seen from their preferences. Different guilds indicate a preference for different habitats (Ding et al. 2019). Suitability of habitat to species of birds found will form a community of birds based on the type of feed guild. Distinguished feeding guilds parameter divided into number of species, proportion of transient individuals,

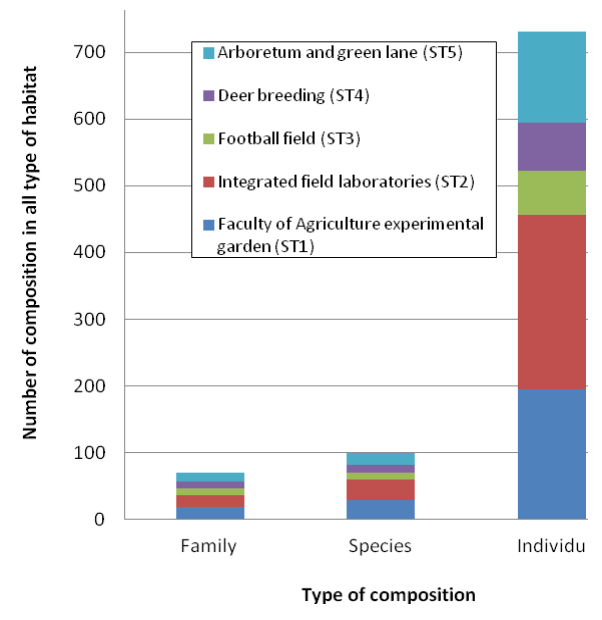

Figure 7. Bird composition based on family, species, and individual in several habitats at UNILA, Bandar Lampung, Indonesia on wet season (WS) and dry season (DS) amount of seasonal variation in abundance, mean body mass, and estimated biomass that can appear to be related to diet characteristics (food types are taken, diet diversity) at the species level (Poulin et al. 1994). Availability of resources, especially feed sources, and their use will affect variations in bird species in each habitat (Rumblat et al. 2016). Thus, the composition of bird species based on guild types found at UNILA illustrates the role and position of each bird in the food chain in an ecosystem and environmental quality.

\section{Level of bird species diversity, evenness, and dominance in various habitats at UNILA}

Five research sites in UNILA have distinguished physical conditions in forming habitats. This is indicated by the diverse composition of family, species, and individual birds found to form communities. The composition of the number of families, the number of species (species), and the number of individuals in each habitat or location understudy is very different (Figure 7). Based on the analysis, Integrated Field Laboratory (ST2) is highest in the number of families, species, and individuals, compared to the other four locations. Faculty of Agriculture experimental garden (ST1) occupies the second-highest position in the number of individuals, species, and families of birds. They were next followed by the Arboretum habitat and the green lane (ST5) and Deer Breeding (ST4). The location where the fewest birds were found was the Soccer Field (ST3).

The results of species diversity and evenness index analysis in five habitats of UNILA can see in Figure 4. Although the average results were not significantly different, the highest diversity index was found in the ST2 habitat with a high category $(\mathrm{H}>3)$. In contrast, species diversity in the four other habitats was classified as moderate (Figure 8).

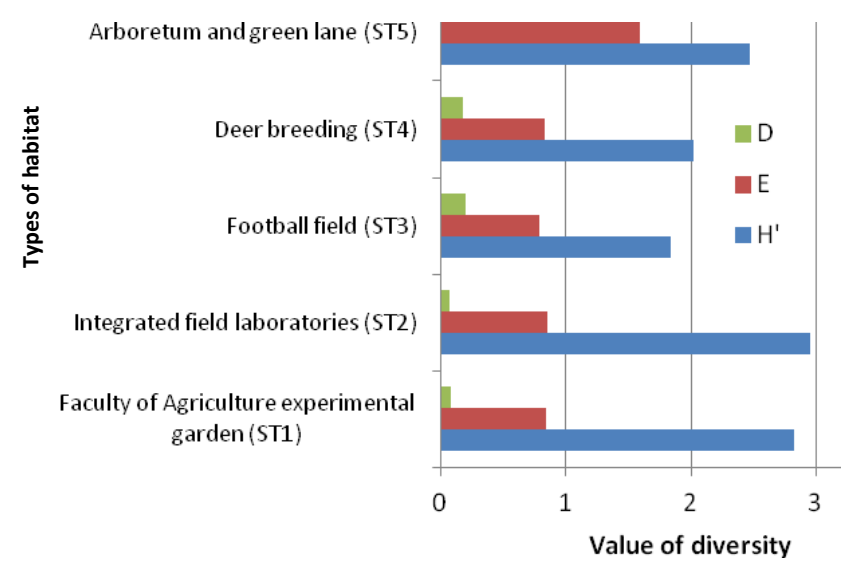

Figure 8. Diversity level (H'), Evenness (E), and Dominance (D) bird species in various habitats in UNILA, Bandar Lampung, Indonesia 
The high number of birds species and diversity index value found in the Integrated Field Laboratory (ST2) allegedly caused by the complexity of its habitat. ST2 has a variety of ecosystems, like aquatic, rice fields, dry agricultural land, and mixed gardens (agroforestry) is sufficient to support the behavior of birds in utilizing habitats. The composition of ST2 vegetation classified as heterogeneous with variations in the structure of the canopy that do not dense provides more food sources, shelter or nesting (cover), and temporary resting places (shelter) to support the formation of more diverse bird communities. This results consistent with the Feroz and Hadi (2016) research that areas with more vegetation cover will occupy more families and species of birds. Suitable habitat tends to be used by bird species as its primary habitat because birds get a source of food and shelter (cover) from predators and bad weather (Rajpar and Zakaria 2011; Wingfield and Ramenofsky 2011; Nugroho et al. 2013). Based on the support of this theory, it can be believed that the Integrated Field Laboratory (ST2) is suitable habitat in supporting the lives of various species of birds at UNILA.

The Faculty of Agriculture experimental gardens (ST1) and Arboretum (ST5) have moderate diversity index values, but it relatively close to high $\left(\mathrm{H}\right.$ 'ST1=2.835 and $\mathrm{H}^{\prime}$ ST2=2.607). But basically, the diversity of 4 locations (including ST1 and ST5) classified as moderate or lower than ST2. It is because the habitat conditions in the four locations are almost similar, which is close to the center of human activity. ST1 is dominated by dry agricultural land and waters. Still, because it is located on the edge of the road, so it is very susceptible to motor vehicle noise and human activities.

In contrast, the habitat condition of ST5 is dominated by tall trees, which are scattered around buildings and roadside and arboretum with tight canopy and very massive activity humans. Tectona grandis dominate the ST4 habitat, and Cassia siamea stands with close canopy cover. Among the habitats of the medium category, the Soccer Field (ST3) has the lowest diversity index value. It is because the ST3 conditions are dominated by short, regular, and broad grasslands but surrounded by trees with a tight canopy and very massive by human activity in the morning and evening. Some of these habitats condition greatly influence the birds' presence and diversity, one of which is due to differences in structure, composition, and diversity of vegetation. That is, the more diverse vegetation, the diversity of bird species tends to increase. It is reinforced by the results of other studies that plants in habitat have a significant influence in attracting the presence of birds (Fernandez-Canero and GonzalezRedondo 2010; Chiquet et al. 2013; Rumanasari et al. 2017). The number of bird species found is affected by canopy openness, the more canopy cover is opened, the more birds will be found, and vice versa (Saefullah et al. 2015). The presence of birds is also influenced by habitat compatibility supported by water availability and abundance of food and shelter from predators (Issa 2019). Also, other factors that influence the support of bird diversity are habitat comfort and security from threats and disturbance due to anthropogenic activity. Human activities during the day and night can disturb birds (Issa 2019). Differences influence the presence of bird species in plant species and supporting habitat conditions, comfort levels, and safety levels of various forms of disturbance (Nurmaeti et al. 2018).

Evenness index (E) between the five habitats is not much different (close to 1) with a range of $0.816-0.866$, which shows the distribution between species is relatively uniform. The results of the dominance index analysis (D) also support this finding, with a range of index values of 0.069 to 0.191 (close to 0 ), indicating that no specific bird species dominates between the five habitats. In other words, all of bird species found categorize as a generalist to habitat, or there are no particular bird species that dominate a specific habitat in UNILA. It might be influenced by the distribution and condition of vegetation in each habitat equal to provide a source of food and a place to nest, breed, rest (perch and explore) in supporting the lives of every wild bird species, thereby minimizing competition due to limited resources.

The theory states that low species evenness was caused by competition in resource use (Kurniawan et al. 2018). Due to limited resources can create competition between species in a region (Ferger et al. 2014). Plants play an important role as a supporting factor for birdlife (Nugroho 2016), so variations in bird species diversity are related to vegetation composition (Kiros et al. 2018). In this study found distribution among identical bird species from $\mathrm{D}$ and $E$ value that an indication of competition absence in utilizing available resources. Bird communities in UNILA quite evenly distribute in each habitat. Besides that, bird diversity closely related to the heterogeneity of the landscape. That is, the more heterogeneous a landscape will be followed by an increasing number of birds (Lee and Martin 2017). The high diversity of bird species in UNILA can indicate habitat heterogeneity and the importance of the region. Furthermore, the importance of sustainable management conducted to ensure the stability of the bird population in the long run.

In conclusion, thirty-seven bird species can be found at UNILA, consisting of 21 families and eight orders. There are nine types of 9 families and three orders that have a widespread in UNILA. The most common order is Passeriformes. Based on the species composition, five members of Cuculidae are the highest family, while the least composition is Sittidae and Oriolidae, each of 1 species. The highest diversity index $\left(\mathrm{H}^{\prime}\right)$ found in ST2 with a high category $\left(\mathrm{H}^{\prime}>3\right)$, while four other habitats have a medium category $\left(\mathrm{H}^{\prime \prime} 3\right)$. Evenness index $(\mathrm{E})$ of the five habitats is close to 1 with a range of 0.816 to 0.866 , which shows the distribution between species is relatively uniform. The dominance index (D) approaches 0 with a range of $0.0816-0.191$, which indicates that no particular bird species dominate in the five habitats. The composition and richness of vegetation in UNILA will affect the bird communities formed in each habitat and indicate the importance of the area so that sustainable management is needed. 


\section{REFERENCES}

Akinpelu OEOAI. 2017. Avian diversity and feeding guilds within Lekki Conservation Centre, Lagos State, Nigeria. Intl J Sci Res. 6(10):724729. DOI: 10.21275/ART20177073.

Callaghan CT, Major RE, Lyons MB, Martin JM, Kingsford RT. 2018 The effects of local and landscape habitat attribute on bird diversity in urban greenspaces. Ecosphere 9 (7). DOI: 10.1002/ecs2.2347.

Chiquet C, Dover JW, Mitchell P. 2013. Birds and the urban environment: The value of green walls. Urban Ecosyst 16 (3): 453-462. DOI $10.1007 / \mathrm{s} 11252-012-0277-9$.

Ding Z, Liang J, Hu Y, Zhou Z, Sun H, Liu L, Liu H, Hu H, Si X. 2019 Different responses of avian feeding guilds to spatial and environmental factors across an elevation gradient in the central Himalaya. Ecol Evol 9 (7): 4116-4128. DOI: 10.1002/ece3.5040.

Domokos E, Domokos J. 2016. Bird communities of different woody vegetation types from the Niraj Valley, Romania. Turk J Zool 40 (5): 734-742. DOI: 10.3906/zoo-1510-64.

Dorrestein GM. 2009. 8 - Passerines. In: Tully TN, Dorrestein GM, Jones AK, Cooper JE (eds.). Handbook of Avian Medicine, 2nd ed. W.B. Saunders, Edinburgh.

Ferger SW, Schleuning M, Hemp A, Howell KM, Böhning-Gaese K 2014. Food resources and vegetation structure mediate climatic effects on species richness of birds. Global Ecol Biogeogr 23 (5): 541-549. DOI: 10.1111/geb.12151.

Fernandez-Canero R, Gonzalez-Redondo P. 2010. Green roofs as a habitat for birds: A review. J Anim Vet Adv 9 (15): 2041-2052.

Feroz DA, Hadi R. 2016. Species diversity and abundance of resident and migratory bird fauna of a North-Western Peri-Urban Area. Karachi 3 . 175-180.

Fikriyanti M, Wulandari W, Fauzi I, Rahmat A. 2018. Keragaman Jenis burung pada berbagai komunitas di pulau Sangiang, Provinsi Banten. Jurnal Biodjati 3 (2): 59-67. DOI: 10.15575/biodjati.v3i2.2360.

Gabbe AP, Robinson SK, Brawn JD. 2002. Tree-species preferences of foraging insectivorous birds: Implications for floodplain forest restorationไrpreferencia de aves forrajeras insectívoras por especies de árboles: Implicaciones en la Restauración de Bosques de Llanuras Inundables. Conserv Biol 16 (2): 462-470. DOI: 10.1046/j.1523 1739.2002.00460.x.

Hong A, Mohd-Azlan J. 2018. The urban avifauna of Kuching, Borneo, and the possible impact of cats on its structure. Kukila 21: 1-12.

Iskandar BS, Iskandar J, Partasasmita R. 2019. Hobby and business on trading birds: Case study in bird market of Sukahaji, Bandung, West Java and Splendid, Malang, East Java (Indonesia). Biodiversitas 20 (5): 1316-1332. DOI: 10.13057/biodiv/d200522.

Issa MAA. 2019. Diversity and abundance of wild birds species in two different habitats at Sharkia Governorate, Egypt. J Basic Appl Zoo 80 (1): 1-7. DOI: 10.1186/s41936-019-0103-5.

Kiros S, Afework B, Legese K. 2018. A preliminary study on bird diversity and abundance from Wabe fragmented forests around Gubre subcity and Wolkite town, Southwestern Ethiopia. Intl J Avian Wildlife Biol 3 (5): 333-340. DOI: 10.15406/ijawb.2018.03.00116.

Kurniawan AJ, Prayogo H, Erianto E. 2018. Keanekaragaman jenis burung diurnal di pulau Temajo Kecamatan Sungai Kunyit Kabupaten Mempawah Kalimantan Barat. Jurnal Hutan Lestari 6 (1): 230-237. [Indonesian]

Lee MB, Martin JA. 2017. Avian species and functional diversity in agricultural landscapes: Does landscape heterogeneity matter? PLoS ONE 12 (1): 1-21. DOI: 10.1371/journal.pone.0170540.

MacKinnon J, Phillipps K, van Balen B. 2010. Burung-burung di Sumatera, Jawa, Bali dan Kalimantan. Burung Indonesia, Bogor. [Indonesian]

Muhammad GI, Mardiastuti A, Sunarminto T. 2018. Keanekaragaman jenis dan kelompok pakan avifauna di Gunung Pinang, Kramatwatu, Kabupaten Serang, Banten. Media Konservasi 23 (2): 178-186. [Indonesian]

Naithani A, Suwanwaree P, Nadolski B. 2018. Bird Community Structure of Suranaree University of Technology Campus, Nakhon Ratchasima Province, Thailand. Pakistan J Zool 50 (4):1257-1265.

Ntongani WA, Andrew SM. 2013. Bird species composition and diversity in habitats with different disturbance histories at Kilombero Wetland, Tanzania. J Ecol 3 (7): 482-488. DOI: 10.4236/oje.2013.37056.
Nugroho J. 2016. Struktur Komunitas burung di Taman Situlembang, Taman Suropati, dan Taman Menteng, Jakarta Pusat. Bioma 12 (1): 32. DOI: 10.21009/bioma12(1).4. [Indonesian]

Nugroho MS, Ningsih S, Ihsan M. 2013. Keanekaragaman jenis burung pada areal dongi-dongi di kawasan Taman Nasional Lore Lindu. Warta Rimba 1 (1): 1-10. [Indonesian]

Nurhasanah N. 2018. Studi keberadaan berbagai jenis burung di Kampus Universitas Lampung. [Hon. Thesis]. Fakultas Matematika dan Ilmu Pengetahuan Alam, Universitas Lampung. [Indonesian]

Nurmaeti C, Abidin Z, Prianto A. 2018. Keanekaragaman burung pada zona penyangga Taman Nasional Gunung Ciremai. Quagga: Jurnal Pendidikan dan Biologi 10 (2): 54. DOI: 10.25134/quagga.v10i2.1297. [Indonesian]

Paramita EC, Kuntjoro S, Ambarwati R. 2015. Keanekaragaman dan kelimpahan jenis burung di kawasan Mangrove Center Tuban Diversity and Abundance of Bird in Mangrove Center Tuban. Lentera Bio 4 (3): 161-167.

Payevsky VA. 2014. Phylogeny and classification of passerine birds, Passeriformes. Biol Bull Rev 4 (2): 143-156. DOI: 10.1134/s2079086414020054

Poulin B, Lefebvre G, Mcneil R. 1994. Characteristics of feeding guilds and variation in diets of bird species of three adjacent tropical sites. Biotropica 26 (2): 187-197. DOI: 10.2307/2388808.

Rajpar MN, Zakaria M. 2011. Bird species abundance and their correlations with microclimate and habitat variables at natural wetland reserve, peninsular Malaysia. Intl $\mathrm{J}$ Zool. DOI: $10.1155 / 2011 / 758573$

Ramadhani RF. 2018. Hubungan keanekaragaman jenis burung dengan komposisi pohon di Kampus Universitas Lampung. [Skripsi]. Fakultas Matematika dan Ilmu Pengetahuan Alam, Universitas Lampung, Bandar Lampung. [Indonesian]

von Rintelen K, Arida E, Häuser C. 2017. A review of biodiversity-related issues and challenges in megadiverse Indonesia and other Southeast Asian countries. Res Ideas Outcomes 3: e20860. DOI: 10.3897/rio.3.e20860.

Rodewald AD, Abrams MD. 2002. Floristics and avian community structure: Implications for regional changes in eastern forest composition. For Sci 48 (2): 267-272.

Rumanasari RD, Saroyo S, Katili DY. 2017. Biodiversitas burung pada beberapa tipe habitat di Kampus Universitas Sam Ratulangi. Jurnal MIPA UNSRAT 6 (1): 43. DOI: 10.35799/jm.6.1.2017.16153.

Rumblat W, Mardiastuti A, Mulyani YA. 2016. Guild pakan komunitas burung di DKI Jakarta. Media Konservasi 21 (1): 58-64. DOI: 10.29243/medkon.21.1.\%p. [Indonesian]

Saefullah A, Mustari AH, Mardiastuti A. 2015. Keanekaragaman jenis burung pada berbagai tipe habitat beserta gangguannya di Hutan Penelitain Dramaga, Bogor, Jawa Barat. Media Konservasi 20 :117124. [Indonesian]

Subasinghe K, Sumanapala AP. 2014. Biological and functional diversity of bird communities in natural and human-modified habitats in northern flank of Knuckles mountain forest range, Sri Lanka. Biodiversitas 15 (2): 200-205. DOI: 10.13057/biodiv/d150212.

Sulaiman S, Mohamad NHN, Idilfitri S. 2013. Contribution of vegetation in Urban Parks as habitat for selective bird community. Procedia Soc Behav Sci 85: 267-281. DOI: 10.1016/j.sbspro.2013.08.358.

Sutopo S, Santoso N, Hernowo JB. 2017. Pola penggunaan ruang dan waktu kelompok burung air pada ekosistem mangrove Muara Bengawan Solo Kabupaten Gresik. Media Konservasi 22 (2): 129137. [Indonesian]

Tesfahunegny W, Fekensa T, Mulualem G. 2016. Avifauna diversity in Kafa Biosphere Reserve: Knowledge and perception of villagers in Southwest Ethiopia Mekelle Biodiversity Centre. Animal Biodiversity Wildlife Study Ethiopia 34 (9): 1222-1229.

Tietze DT. 2018. Bird Species: How They Arise, Modify and Vanish. Springer Open, Berlin.

Whelan CJ, Wenny DG, Marquis RJ. 2008. Ecosystem services provided by birds. Ann NY Acad Sci. 1134: 25-60.

Winara A. 2016. Keragaman jenis burung air di Taman Nasional Wasur, Merauke. Jurnal Hutan Tropis 4 (1): 85. DOI: 10.20527/jht.v4i1.2885. [Indonesian]

Wingfield JC, Ramenofsky M. 2011. Hormone-behavior Interrelationships of Birds in Response to Weather. 1st ed. Elsevier Inc., Nederlands.

Xu Y, Si Y, Takekawa J, Liu Q, Prins HHT, Yin S, Prosser DJ, Gong P, de Boer WF. 2019. A network approach to prioritize conservation efforts for migratory birds. Conserv Biol. DOI: 10.1111/cobi.13383. 